University of Wollongong

Research Online

Faculty of Commerce - Papers (Archive)

Faculty of Business and Law

$1-6-2006$

\title{
The influence of religion-based workplace spirituality on business leaders' decision-making: An inter-faith study
}

Mario Fernando

University of Wollongong, mariof@uow.edu.au

B. Jackson

Victoria University of Wellington, New Zealand, B.jackson@auckland.ac.nz

Follow this and additional works at: https://ro.uow.edu.au/commpapers

Part of the Business Commons, and the Social and Behavioral Sciences Commons

\section{Recommended Citation}

Fernando, Mario and Jackson, B.: The influence of religion-based workplace spirituality on business leaders' decision-making: An inter-faith study 2006.

https://ro.uow.edu.au/commpapers/165

Research Online is the open access institutional repository for the University of Wollongong. For further information contact the UOW Library: research-pubs@uow.edu.au 


\title{
The influence of religion-based workplace spirituality on business leaders' decision-making: An inter-faith study
}

\author{
Abstract \\ The paper reports the findings of thirteen interviews with prominent Sri Lankan business leaders drawn \\ from Buddhist, Christian, Hindu, and Muslim religious traditions. The in-depth interviews with the leaders \\ were supplemented by documentary sources. When the leaders were asked why they engaged in religion- \\ based workplace spirituality, their responses were often associated with decision-making. Although they \\ had an array of management tools with which to deal with day-to-day management situations, they all \\ indicated that, in 'difficult' moments, these tools needed to be complemented by processes by which they \\ connected with the ultimate - variously identified as the transcendent reality, god, or truth that is more \\ powerful, better, and good. The outcomes of decisions, both good and bad, were usually attributed to that \\ connecting experience. The findings suggest that religion plays a significant role in influencing the \\ judgment, emotional and motivational qualities of Sri Lankan leaders' decision-making - in that a frame \\ of eference based on a connection with a transcendent and ultimate reality is likely to be a source of \\ solace, guidance, and inspiration to leaders' critical decision-making.

\section{Keywords} \\ religion-based workplace spirituality, decision-making, connectedness, unbounded rationality, interfaith, \\ Sri Lanka

\section{Disciplines} \\ Business | Social and Behavioral Sciences

\section{Publication Details} \\ This article was originally published as: Fernando, M \& Jackson, B, The influence of religion-based \\ workplace spirituality on business leaders' decision-making: An inter-faith study, Journal of Management \\ \& Organization, 2006, 12(1), 23-39. Copyright eContent Management Pty Ltd, 2006. The original journal \\ can be found here.
}




\title{
The influence of religion-based workplace spirituality on business leaders' decision-making: an inter-faith study
}

Received October 1, 2005 Accepted March 8, 2006

\author{
Dr. Mario Fernando \\ Lecturer \\ School of Management and Marketing \\ University of Wollongong \\ Northfields Avenue, NSW2522 \\ Australia \\ Dr. Brad Jackson \\ Director \\ Centre for the Study of Leadership \\ Victoria University of Wellington \\ Wellington, \\ New Zealand.
}

\begin{abstract}
The paper reports the findings of thirteen interviews with prominent Sri Lankan business leaders drawn from Buddhist, Christian, Hindu, and Muslim religious traditions. The in-depth interviews with the leaders were supplemented by documentary sources. When the leaders were asked why they engaged in religion-based workplace spirituality, their responses were often associated with decision-making. Although they had an array of management tools with which to deal with day-to-day management situations, they all indicated that, in 'difficult' moments, these tools needed to be complemented by processes by which they connected with the ultimate-variously identified as the transcendent reality, god, or truth that is more powerful, better, and
\end{abstract}


good. The outcomes of decisions, both good and bad, were usually attributed to that connecting experience. The findings suggest that religion plays a significant role in influencing the judgment, emotional and motivational qualities of Sri Lankan leaders’ decision-making —in that a frame of reference based on a connection with a transcendent and ultimate reality is likely to be a source of solace, guidance, and inspiration to leaders’ critical decision-making.

Keywords: religion-based workplace spirituality, decision-making, connectedness, unbounded rationality, interfaith, Sri Lanka

An earlier version of this paper was presented at the European Group of Organization Studies Colloquium, Berlin, 2005.

\section{INTRODUCTION}

The prevailing spiritual revival in the workplace reflects, in large part, a broader religious reawakening in America. It has taken shape over the past twenty years, originating and being developed almost wholly in the West, within a predominantly Judaeo-Christian perspective. The burgeoning workplace spirituality literature has been mainly influenced by developments in the fields of religious studies and psychology (Giacalone, Jurkiewicz and Fry, 2005; Gibbons, 2000; Joseph, 2002; Snyder and Lopez, 2001). Recent contributions to workplace spirituality literature by an impressively expanding group of researchers focus on the influence of religion on managing and leading organisations (Dent, Higgins and Wharff, 2005; Kriger and Seng, 2005; Whittington, Pitts, Kageler and Goodwin, 2005). 
The role of religion in workplace spirituality is a hotly debated issue. Some researchers argue that spirituality can be identified and defined independently of any religious context (Giacalone and Jurkiewicz, 2003; Paloutzian and Park, 2005; Zinnebauer and Paragament, 2005). They argue that spirituality is something that is not confined to religion. It can also be about a sense of purpose, meaning and connectedness to one another (Fernando, 2005a). In this argument, religion has no role in defining spirituality and workplace spirituality. For example, Giacalone and Jurkiewicz define workplace spirituality as “...a framework of organizational values evidenced in the culture that promotes employees' experience of transcendence through the work process, facilitating their sense of being connected to others in a way that provides feelings of completeness and joy” (2003: 13). As several other writers point out, this view does not take into account the complex depth and richness that the term spirituality actually connotes (Dent, Higgins and Wharff, 2005; Kriger and Seng, 2005).

Thus, another group of commentators tie spirituality with religion. They specifically link the definition of spirituality with religious practice. For example, Kriger and Hanson (1999) suggest that the world's major religious traditions have endured the test of time and note that the values inherent in those religions may be relevant to the management of modern organisations. Korac-Kakabadse, Kouzmin and Kakabadse (2002) state that spirituality includes terms such as energy, meaning, and knowing, and relates to the various spiritualities of Tao, Buddhism, Hinduism, Zen, and Native American spirituality. According to this strand of the argument, religion cannot be excluded in examining spirituality because one interprets the other and religious values help members make sense of unexpected events. More recently, in a meta analysis of workplace literature, Dent, Higgins and Wharff (2005) conclude that spirituality should be defined in a context that takes religion into consideration. This call is further accentuated by Kriger and Seng (2005) who claim that in mid-2003, an 
estimated $82 \%$ of the world's population believed or followed a religious or spiritual tradition.

However, religion-based workplace spirituality can lead to arrogance that a particular faith is better, morally superior, or more worthy than another. Forcing a specific religionbased workplace spirituality—particularly the organisational leader's religion—onto other organisational members raises some potential concerns. It could result in coercion and/or favouritism towards those with similar religious beliefs as the leader. Viewing workplace spirituality through the lens of a specific religious tradition as the only path to the ultimate is divisive because it excludes those who do not share in that tradition (Hicks, 2002). Imbuing religion into workplace spirituality can foster zealotry at the expense of organisational goals, offend stakeholders and decrease morale and employee well-being (Giacalone and Jurkiewicz, 2003).

While recognizing the salience of the non-religion-based workplace spirituality, the following paper is firmly anchored within the perspective of religion-based workplace spirituality which is associated with the practice of faith traditions. We report the findings of an empirical study that examined the influence of religion-based spirituality on the decisionmaking processes of business leaders operating in Sri Lanka drawn from Christian, Buddhist, Hindu and Muslim faiths. Employing a qualitative, case study approach, we investigate conceptions of spirituality in 13 Sri Lankan business leaders. Based on our findings, we identify 'right' decision-making as a common need of these business leaders in Sri Lanka. Leaders attributed the origin of this sense of rightness to religious faith. They wanted to avoid doing business in a way that they thought was harmful. We find that this process was driven by the need to relate or connect to one's ultimate-variously identified as the transcendent reality, god, or truth that is more powerful, better, and good. 
The rest of the paper is arranged as follows. First, we introduce the research context and provide a brief review of the major religions practised in Sri Lanka. Second, we review the literature on decision-making and religion-based workplace spirituality. Third, we discuss the methodology of data collection and analysis used in this study. Fourth, we discuss our findings and conclude with a discussion of their implications of their findings for workplace spirituality and future research.

\section{RESEARCH CONTEXT}

The business leaders of the multireligious, multiethnic and multilingual Sri Lankan culture are products of a whole host of influences from the neighbouring giant-India. These include a caste system, Western occupation and national cultural values. With a per capita income of over US\$ 1000, Sri Lanka has attracted several Fortune500 companies which have located their regional offices in this country (Asian Tribune, 2005). Paralleling this commercial activity had been a call by various researchers for increased efforts directed at studying the Sri Lankan market (Chandrakumar and Sparrow, 2004).

Sri Lanka's population of 19 million consists of three major ethnic groups: Sinhalese (74 per cent), Tamils (17 per cent) and Muslims (8 per cent). Its main religions are Buddhism (69 per cent), Hinduism (15 per cent), Christianity (8 per cent) and Islam (8 per cent). Thus, Sri Lanka represents one of the world's most highly religious and diverse cultures - with a wide variety of religious expression being apparent among the various groups of the island (Jones, 1997). Due to a unique cultural system that has been formed by a process of syncretic fusion embedding various religious elements, religion influences almost every aspect of peoples' lives in Sri Lanka (Gombrich and Obeyesekere, 1988). The contemporary Sri Lankan religious practices are based on many distinct beliefs and value systems. 
Tambiah (1986) asserts that Buddhism in contemporary Sri Lanka has lost its ethical and philosophical bearings and has become a set of ritualized devotions, undertaken by believers to obtain worldly good fortune. In the Sri Lankan Buddhist practices, many cult, daemons and Gods are worshipped for material benefits. Furthermore, some of the Buddhist practices are conducted according to cultural expectations and norms.

Hinduism in Sri Lanka is closely related to the distinctive cultural systems of neighbouring Tamil Nadu in India (Arasaratnam, 1964). Although several Gods predominate in the many myths, legends, and styles of worship, 'the Hindus of Sri Lanka are almost exclusively Saivites-Lord Siva was to them the most important God in the Hindu pantheon' (Arasaratnam, 1964: 113). Some Gods such as Vishnu is worshipped by both Sinhalese and Hindus.

Christianity is first mentioned around 525 A.D. by Sopater, a Greek merchant who went to Sri Lanka from Abyssinia in a Persian ship (Elliott, 1938) and made significant inroads only after the fifteenth century, as aggressive Portuguese missionary efforts led to many conversions. When the Dutch took control of Sri Lanka, they formed their own missionary organisation under the Dutch Reformed Church. The British, in turn, allowed Anglican and other Protestant missionaries to proselytize. Since the 1970s, there has been a movement of all Protestant Churches to join in a united Church of Sri Lanka. Sri Lankan Christians today are mostly Roman Catholic and have special places of worship in the island. Early Muslims in Sri Lanka spoke Arabized Tamil rather than pure Arabic (Arasaratnam, 1964). Their families followed Islam and preserved the basic doctrines and Islamic law, while also adopting some local social customs that were not part of early Islamic society in the Arabian Peninsula. Today the Sri Lankan Muslim community is made up of Moors, Malays and Indians. Sri Lankan followers of these faith traditions while retaining their separate religious identities have adopted some aspects of popular religion. 
Popular pilgrimage sites such as Kataragama is worshipped by followers from all faith traditions.

The modern Sri Lankan leader of any religious tradition is highly collectivist and shows a need for affiliation (Chandrakumar and Sparrow, 2004). The concept of individual achievement, which is critical for stimulating entrepreneurship according to the Western view, is not a dominant concern in Sri Lanka. According to the studies that have been conducted on Sri Lankan business leaders, they tend to posses the following characteristics. First, work appears to be closer to the leaders’ life and family (Perera and Buddhadasa, 1992; Ranasinghe, 1996a and 1996b); Second, business leaders appear to seek not only money and material benefits from their work, but also self-satisfaction from mental engagement (Batten, Hettihewa and Mellor, 1999; Niles, 1994). Third, the pervasive influence of Buddhism on the people of Sri Lanka may have engrained certain social attitudes such as philanthropy, which was perceived necessary to achieve prescribed mental characteristics in human life (Nanayakkara, 1997).

To summarise, it seems that the Western focus on individual achievement is less pronounced within the social-cultural context of Sri Lanka. This paper aims to cast light on the various ways in which religion actually affects leaders' decision-making albeit from a distinctive social and cultural milieu.

\section{THE PLACE OF RELIGION-BASED SPIRTUALITY IN DECISION-MAKING AND LEADERSHIP}

Decision-making in the management literature is explained through a number of distinct models among which the rational, cybernetic, political, incremental and garbage-can are some of the more well-known (Bazerman, 2002; Beyer, 1981; Daft, 2001; Harrison, 1999; March, 1994). At the centre of any decision-making process is the individual decision-maker who experiences demands and pressures from a number of sources. 
The role of the decision-maker in the managerial decision-making process is a complex one. He or she operates in an organisational environment which, in turn, reflects demands from external sources. In addition, these individuals have to interact with other members of the organisation such as their peers, superiors and subordinates, and this interaction influences their behaviour. Decision-makers are also expected to perform their assigned tasks by utilising their skills and authority within the organisation. The decisionmaking process is finally tempered by the decision-maker's personal characteristics such as his or her values, beliefs, needs and proficiency that may influence how he or she reacts to environmental, organisational and task demands. Personal values of the decision-maker instigate the dominant level input into the decision-making process (Fritzsche, 1991) and could be a predictor of decision outcomes (Barnett and Karson, 1987). Because of this, it is highly probable that religion could play a significant role in the decision outcomes of individuals whose personal characteristics are shaped by their religious orientation.

Religion-based decision-making could be associated with what is currently identified as intuitive decision-making. According to Burke and Miller (1999), intuitive decisionmaking is a subconscious process of making decisions based on experience and accumulated judgment. They describe five different aspects of intuition; subconscious mental programming, values or ethics-based decisions, experience-based decisions, affect-initiated decisions and cognitive-based decisions. In the case of a leader influenced by religion-based spirituality, all these aspects could play critical roles in the outcome of a decision.

For example, Longenecker, McKinney and Moore’s (2004) study of 1,234 business leaders in the US found evidence of a significant religious factor in ethical decision-making. Religiosity has been found to influence marketers' ethical decision-making process (Hunt and Vitell, 1993). Hunt and Vitell state, “Unquestionably, an individual’s personal religion influences ethical decision-making. A priori, compared with nonreligious people, one might 
suspect that the highly religious people would have more clearly defined deontological norms and that such norms would play a stronger role in ethical judgments” (1993: 780). Singhapakdi et al. (2000) claim that religiosity affects the ethical decision-making process in different ways. A more religious person, because of the codified value system, could possibly have a higher moral standard than a less religious person. However, organisational and environmental pressures exerted on a leader can compromise this standard so that even the most religiously devout leader may be forced to make a less than optimal decision.

Several recent theoretical contributions to workplace spirituality literature have focused explicitly on the relationship between religion and leadership. One of these pioneering studies examined how theorists might fruitfully incorporate the inner values of major religious traditions into contingency theory of leadership (Kriger and Seng, 2005). It identified similarities and differences in the implicit leadership models among five religious traditions, and propose an integrative model of organisational leadership based on inner meaning, leader values, vision and moral examples at multiple levels of being. Others have examined how religious values could be considered in developing legacy leadership (Whittington et al., 2005) and spiritual leadership (Fry, 2003; 2005).

Despite the impressive increase in the volume and rigour of scholarly articles that examine the role of religion in leadership, there is yet a lack of empirical evidence to cast light on the various ways in which religion actually affects leaders' decision-making, planning and control processes. This line of inquiry could not only establish the role of religion in leadership but also demonstrate how religiosity could be embedded in the sensemaking processes of basic management functions such as decision-making (Weick, 1979; 1985). The following empirical study is a necessarily exploratory study that aims to examine the various ways in which religion-based workplace spirituality may affect leaders’ decision-making. 


\section{METHODOLOGY}

\section{The Sample}

The fieldwork for the present study was conducted in Colombo, Sri Lanka over two months during 2002/3. The method for selecting participants was purposive because the study set out to learn about workplace spirituality from typical cases of leaders who were known to practice workplace spirituality (Patton, 2002). The business leaders were selected on the basis that they were spiritually motivated—that is, they had publicly acknowledged their spiritually motivated approach to heading business organisations, and were identified as such by others in their communities, most especially the media. The thirteen participants in the study led large organisations and were all highly visible business people in Sri Lankan society. Their life stories in many instances have become part of the business folklore in the country. The participants were all born, raised, and educated in Sri Lanka and their primary businesses, families, and social networks were in Sri Lanka. The sample consisted of four chairpersons, six managing directors (one retired) and three directors heading organisations in the consumer, industrial and service sectors with an approximate total of 14315 employees. Seven of the leaders were Buddhists, two Hindus, three Christians (two Roman Catholic and one Anglican) and one Muslim.

\section{Data Collection and Analysis}

The primary method of data collection was in-depth face-to-face interviews. A semistructured interview guide was used. The questions focused primarily on two topics: the meaning of spirituality and the enactment of workplace spirituality. We designed questions that were broad enough to capture a wide range of experiences and narrow enough to elicit and explore each participant's specific experiences. Additional probing questions were interwoven during each interview to seek verification and explanation. To seek the participants' perspectives on the phenomenon under study, the interview guide was based on 
an open-ended format. This format was used to encourage participants to share information in a style that they were comfortable with. To further ensure the appropriateness of the research methods, these data collection procedures were first pilot tested.

According to Miles and Huberman (1994), the key to ensuring the quality of data in a study of this type is to link three levels of understanding-(i) the meanings and interpretations of the participants; (ii) the researcher's interpretation of those meanings; and (iii) confirmatory analysis. Unfortunately, this linking process cannot be made explicit in this paper because data collection was governed by a confidentiality agreement. Data triangulation was, therefore, used to ensure the quality of the data, together with multiple methods of confirmatory analysis including methodological triangulation (Seale, 2000).

With respect to data triangulation, to strengthen and verify the use of the interview data, additional information was sought through the review of relevant company and public documents. Organisational documents included annual reports, photographs, newspaper cuttings, certificates and web sites. Public documents included media reports collected since 1970 that featured the leaders and their organisations which were held in the archives of leading Sri Lankan media organisations. These reports played a critical role in substantiating the accuracy of the data. For example, an Anglican leader's interview data portrayed him as a God-fearing businessperson. He claimed that he had ' $100 \%$ faith in God'. Over the years, media reports have also portrayed him similarly. A media report seven years earlier had commented that, more than anything else, three factors have been responsible for this leader's business success: first was his faith in God. To further deepen the data quality, the leaders’ moods, hesitancies and expressions were also observed and recorded. Given the nature of the topic, it was felt these might help to assess the sincerity of their accounts.

\section{Grounded Theory Framework}


In this study, the primary method adopted to generate theory from data was a variant of the grounded theory framework. Grounded theory was developed for, and is particularly suited to the study of behavior (Charmaz, 2002; Easterby-Smith, Thorpe and Lowe, 1991; Strauss and Corbin, 1990). It, therefore, has considerable potential within the field of workplace spirituality, particularly if the objective is to understand the processes involved in enacting spirituality in organizations. The process adopted in this study is more in line with the work of Charmaz (2002) and Strauss and Corbin (1990).

Charmaz (2002) identifies a variation of grounded theory-the constructivist's approach to grounded theory. Grounded theory can be applied through a constructivist or objectivist approach. We have placed priority on the phenomenon of study of workplace spirituality and see both data and analysis as created from the shared experiences of the researchers and participants, and the researchers' relationship with the participants. For example, at the beginning of the interview, the lead author explained the personal and academic significance of the study. Consequently, we believe that the resulting responses were co-created. We have not treated the data as being objectively 'real' as an objectivistoriented researcher would. We did not believe that data carried knowable facts about the world. This perspective, according to Charmaz (2002) assumes 'an external reality awaiting discovery and an unbiased observer who records facts about it' (p. 677). On the contrary, we believe we have been creators of the research or what is generally defined as being 'constructivist' in our approach (Charmaz, 2002). We have assumed that the research participants could and would relate significant meanings about their situations to us. Their responses to our questions were assumed to be accurate reflections of their meanings because of their ability to comprehend the meaning of the question and willingness to relate their stories, fully and accurately. 
Theory building within a grounded theory framework also relies on comparative methods (Charmaz, 2002). Emerging themes were sorted based on similarities and differences between leaders' accounts. Through comparative methods, grounded theorists are supposed to define the properties of categories and specify the conditions under which categories are linked to other categories. In this way, categories were raised to a conceptual level. The categories which best explain the study became concepts to be used in theory building (Charmaz, 2002).

According to Charmaz (2002), all variants of grounded theory include some common strategies. One is simultaneous data collection and analysis. In this study, leaders were interviewed twice (i.e. through multiple sequential interviewing). The first interviews were conducted face-to-face and the second round of interviews were conducted in order to fill in missing and incomplete data (Strauss and Corbin, 1990). In the second round, seven interviews were conducted via telephone, two face-to-face and the rest via electronic mail. The grounded theory approach also pursues emergent themes through early data analysis and attempts to discover basic social processes within the data. This was evident from the present study through the process of identifying the role of spiritual practices in the daily lives of leaders. Leaders were asked to relate their daily routine to examine how and when their spiritual practices took place. The present study also generated themes and theories based on the inductive construction of categories that explained and synthesize these processes. Finally, the study also attempted to integrate these categories into a theoretical framework that specified causes, conditions and consequences of enacting workplace spirituality (Strauss and Corbin, 1990).

Through the grouping of responses on spirituality, we collected 81 statements and labelled them within a 'spirituality statement' file. If data from one group were relevant to others, we copied them to each group. The colour coding and review facility in Microsoft 
Word was used to avoid errors in cutting and pasting. We carried out an initial coding process. An excerpt from this file is provided in Table 1.

\section{Insert Table 1 about here}

The phrases in the lower case represent these statements, which were the first eight statements in the spirituality statement file. These statements were further condensed to facilitate the analysis process. The major condensed representative statements (refer to phrases in capitals - Table 1) were identified and copied into a file of themes. These themes represented a composite of data that constituted a meaningful unit. These items became a numbered list of themes and it was useful to further reduce data in a systematic way. We then began to focus on selected and relevant categories of the phenomenon under study which Charmaz (2002) has termed selective or focused coding.

Insert Figure 1 about here

Using a grounded theory framework, each of the themes were then raised to a category and subsequently, to a concept level. This process is illustrated in Figure 1. By way of example, when the leaders attempted to explain their understanding of spirituality, they mentioned specific instances in which they engaged in meaningful charity. This theme was derived from several interviews and was categorised under the 'altruism' label, and subsequently it was raised to a concept level, 'accommodating others'. 


\section{FINDINGS}

Two of the highest order concepts to emerge from our study were the meaning of spirituality and how this meaning was manifested in the workplace through decision-making activities. It is to these that we now turn.

\section{The Meaning of Spirituality}

The majority of the leaders explained their spirituality on the basis of their religious faith. From an early age, all leaders had practised their religions. Many of these leaders started their careers at the end of World War II. At this time, Sri Lanka (then Ceylon) was gradually inching its way towards independence from its colonial status. These individuals belonged to the new generation of youth who were building the new nation. Some of them were from humble backgrounds, starting their businesses with very little personal capital. Some had walked for miles barefoot to school, had slept on pavements and had undergone severe hardships before they came to enjoy their business success. Although many are now of an age at which most people would have retired, they remain active and sharp in their business dealings.

Although they typically had a significant amount of faith in themselves, most leaders attributed their present success to the protection and guidance of an ultimate reality or truth. Several of the leaders have done what they felt was right and just. In spite of major setbacks, they recovered due to their unshakable faith in God. Although the meaning of spirituality as expressed by the various leaders had certain elements in common, no universal definition of the concept emerged. For example, one Buddhist business leader stated that, 'it [spirituality] is a source of guidance to my conduct. I seem to identify spirituality built by a concept of Buddhist faith'. A Roman Catholic leader remarked, 'I think spirituality comes from everybody else who does the right thing with any religious practice or whatever it is .... There is sacredness - and spirituality to me is God fearing'. For the Hindu leaders in the 
study, spirituality was primarily centered on praying. One Hindu leader claimed that 'I pray at least 5-6 times a day. I pray after coming into the office. For me, prayer is a dialogue'. The Muslim leader felt that spirituality ‘is basically a guide system - the ethics. Do’s and don'ts to rule your life and family and whatever you are in charge of. The value principles, which are held near and dear to me'.

The religious expressions of the leaders at work were evident through their practice of various types of religious observance. These practices had one common aim—connecting with a transcendent and ultimate reality — variously named as 'God', the 'Divine', 'Entity', or 'Reality'. Religious practices were the most commonly used mode of experiencing a connection with this transcendent reality. For example, Buddhist leaders engaged in worshipping Buddha statues at work, daily collective meditation (reflection), annual pilgrimage and regular stanza chanting. The Hindus conducted puja ceremonies and recited mantra at work to celebrate important religious and/or corporate events. Christians celebrated holy mass at work and worshipped various religious symbols. The Muslim leader led his business based on the principles of Islam. For the purposes of consistency, the present study uses the term 'ultimate' to denote the leaders' references to the 'God', 'transcendent reality' or 'truth' through which the leaders searched for inspiration, solace, protection, guidance, and an increased sense of inner well-being.

\section{Decision-making}

When the leaders were asked why they engaged in religious practices at work, their responses were often closely associated with decision-making. Although they had an array of management tools with which to deal with day-to-day management situations, they suggested that, in difficult moments, these tools needed to be complemented with taking time to connect with the ultimate. The outcomes of decisions, both good and bad, were 
invariably attributed to this connecting experience. For example, a Hindu business leader in explaining how he was influenced by his spirituality when making decisions noted:

Sometimes you take a certain amount of risk and you wonder what your chances are. ... it might be a weakness in me. I sit and think—pray to God [and I ask] whether I am doing the right thing, am I going the right way? ... I have to make the right decisions.

This participant admitted that he tended to ask for guidance from the ultimate when he was faced with critical decisions associated with managing large projects. He felt a need to conform to a right way of doing things-as determined by his faith in the ultimate. As he said, 'perhaps it is psychotic but I have done this for the last 30-35 years. I feel it makes me a better man and it helps me to take the right decisions'. This need to make 'right decisions' was central to most of the leaders (refer to table 2).

Insert Table 2

During challenging decision-making situations, the leaders felt a general need to draw from their spirituality to find the 'right way' of managing the situation. For example, the business operations of the Anglican participant generate a huge annual financial turnover. Emphasising his commitment to the 'right way' of managing his large business, he observed:

At this moment, one operation is suffering because the competitors in the market don't issue bills. Tax and defence levy is quite high (20\% at selling point). Even if I have to close down, I won't do that in my business. I am losing now, but finally, I think it will come out in a better way. 
Similarly, a Roman Catholic participant emphasised how his decision-making attempts to avoid unethical business activities. He admitted that his organisation was losing market share due to his ethical stance in a business environment in which unethical practices are an accepted norm. Nevertheless, he said:

I used to think about losing the business. But then you also think that you have survived all these years. I used to always think that God will help me somehow. So there is that divine sense of confidence that, some day, you will be taken through tough times. And it helps.

When they made decisions in the 'right way', the leaders spoke of increased happiness, contentment, and a higher sense of inner well-being. Although the literature on workplace spirituality does not, as yet, include a single empirical study of the process of 'right' decision-making, the decision-sciences literature does contain Shakun's (1999, 2001) theoretical contributions to the concept of 'unbounded rationality'. Shakun's contributions have several similarities with the present study's findings on 'right decision-making'. It is to these that we now turn.

\section{CONNECTEDNESS AND RIGHT DECISION-MAKING}

According to Shakun (1999, 2001), rational actions are reasonable actions, that is, they are based on reason, in terms of the goals they set out to achieve. Reasonableness is assessed on the basis of the relationship between the action and the goals. Shakun (2001) also noted that Simon's (1978) substantive and procedural rationality is consistent with the dictionary meaning of rationality. According to Shakun, the emphasis here is on reasoning. However, when individuals make spiritually motivated decisions that result in 'right' decisions, they go beyond Simon's $(1955 ; 1956)$ notion of bounded rationality. Shakun claims that 'right' decisions are not only bounded by cognition, but also by affection and conation. Conation refers to the connection of knowledge and affect to behaviour and is associated with the 
question of 'why?' something has happened. It is the personal, intentional, goal-oriented or striving component of motivation - the proactive (as opposed to reactive or habitual) aspect of behaviour (Huitt, 1999). It is defined as the use of will or the freedom to make choices about what to do. According to Huitt (1999), conation becomes critical when an individual wants to successfully engage in self-direction and self-regulation.

Shakun also points out that 'right' decision-making and 'rightness' originate from spirituality - that is, a consciousness experiencing oneness. Shakun refers to this decisionmaking process in terms of 'unbounded rationality' and claims that it is 'the rationality that ultimately matters, that requires and delivers spirituality’-our ultimate purpose and value (2001: 112-113). 'Right' decision-making is rational or reasonable not only in terms of achieving its goals in terms of cognitive abilities, but also in terms of the ability to experience and act according to a connection with a larger, ultimate whole. Several of these ideas resonate with the key themes that emerged from the interviews conducted with the business leaders in the present study.

The notion of a connection with an ultimate was central to the experience of spirituality as relayed by the Sri Lankan business leaders in the present study. Similarly, according to Shakun (2001), 'right' decisions and 'rightness' are also based on the experience of connectedness. This connectedness is in relation to an entity which Shakun defines as 'all there is, the absolute, the implicate order, the quantum vacuum, emptiness, God' (2001: 103). He labels this entity as 'the One'. As noted above, on the basis of the leaders' descriptions in the present study, the 'ultimate' was defined as the transcendent reality, god or truth that is more powerful, better, and good. The 'ultimate' discussed in the present study and 'the One' discussed in Shakun's study carry a common meaning. Explaining the process of 'connectedness', Shakun notes that 'what we normally term decision-making (conscious decision-making) is a manifestation of consciousness' (2001: 
104). As such, the decision-making process operates through cognition, affect and conation. When consciousness is experiencing connectedness with 'the One', cognition, affect, and conation (as manifestations of consciousness) experience connectedness as oneness, love and perfect action. The absence of such a connectedness with 'the One' (i.e. non-connectedness) is experienced through cognition, affect, and conation as separateness, fear, and nonconnected action. Conflicts in information, values, goals and controls are potential sources of separateness and fear in non-connected action.

Several leaders spoke of instances when the 'right' decision-making process had to be compromised due to conflicting factors that influenced their decision-making processes. In this regard, the impact of organisational and environmental pressures in suppressing the 'right' way of making decisions and forcing them towards non-connectedness was notable and exemplified in several accounts of leaders. A Buddhist leader, who heads one of the largest publicly listed organisations in Sri Lanka, explained that, when the company is in a financial downturn, he cannot pay annual employee increments-although he wished that he could do so. He explained:

If it is justified, I will not give increments. If I feel the decision is going to help the company in the long run, then I would take that decision.

It should be noted that his justification or rationalisation was expressed in terms of the action (stopping increments) and the goal (helping the company in the long run). Emphasising the impact of organisational and environmental pressures on the outcome of this decision, he observed:

I'm a businessman and my job is to deliver to the shareholders. Some of my shareholders are pensioners and they believe in me. I'm the head of this company and therefore, they believe that their investments [will] be safe. Apart from my spirituality, I have to look at the shareholder needs as well. 
The dividend income they get is part of their annual earnings and they depend on that income to keep the home fires burning. Similarly, I have to look into the concerns of employees, consumers, the government, the parent company and suppliers. What people don't realise is that the CEO has a huge responsibility.

Commenting on how he feels after making these types of decisions, he remarked:

It would trouble me up to a point. But I feel if it has to be done, it has to be done. And it is not an immoral decision. Once I clear my conscience that I have done the right thing, I am OK.

He felt the need to do the 'right thing' - 'right' in this instance being fair in terms of the shareholders, rather than the employees. From an employee perspective, the decision to stop employee increments (which are usually paid annually in most organisations in Sri Lanka) was thought to be a 'harsh measure', and it troubled him.

When leaders made the decisions that troubled them and had to clear their conscience, in Shakun's (2001) view, they experienced non-connectedness and separateness. As highlighted by the Buddhist leader's dilemma described above, in certain business situations, pressures from other stakeholders can influence a spiritually motivated business leader to assign priority to cognitive factors at the expense of affective and conative factors. According to Shakun's interpretation, leaders then experience non-connectedness, which results in separateness and fear. They try to overcome the separateness and fear by rationalising the consequences of such a decision to clear the conscience. Another Buddhist leader admitted in his interview that the clearing of his conscience was based on the values promoted by the five precepts of Buddhism. Citing an example of a disciplinary inquiry of an employee accused of theft, he said that his senior managers had found the employee guilty and had decided to terminate his employment. However, in the view of the leader, the 
accused employee was innocent and, before making a decision on terminating his employment, the leader felt a need to consider the Buddhist precepts. He observed, 'I think within the five precepts whether I am right or wrong. Every time I take a decision, I think within these five precepts'.

In summary, faced with challenging and important decision-making situations, interfaith Sri Lankan business leaders in a central and important way referred to a connection with an ultimate ideal. This finding suggests that a frame of reference based on a connection with a transcendent and ultimate reality is likely to be a source of inspiration, guidance and solace to aid the leaders make the 'right' decision. However, the leaders' right decisionmaking process was dependent upon a spirituality that was moderated by the needs of the organisation's shareholders and employees. The findings of the present study are also unique to the historical, geographical and cultural specificities of the participating Sri Lankan leaders.

In terms of socio-cultural factors, the Sri Lankan collectivist culture is known to reflect a high need for affiliation (Carter, 1979; Ranasinghe, 1996a). Consequently, this cultural characteristic among Sri Lankan people could result in a higher level of regard for others' welfare, and therefore, emphasise the need to accommodate others in the decisionmaking process. This could have contributed to the leaders' common need to make 'right' decisions.

The findings of our study have to be interpreted with the knowledge that heterogeneity in terms of race of the participants are not accounted for. Although all Sinhalese living in Sri Lanka are not Buddhists, all Buddhists are Sinhalese (Obeyesekere, 1975). The Christian population could be of Tamil or Sinhalese origin. The Muslims would mainly consist of Tamils. In this interfaith study, the business leaders represented the 
Sinhalese, Tamil and Borah communities and the resulting cultural differences arising from different ethnic backgrounds could have influenced the leaders’ behaviour patterns.

A predominantly religion-based cultural system could also have influenced the 'right' decision-making behaviour of the business leaders. This could be the result of a unique cultural system that has been formed through a process of syncretic fusion embedding various religious elements (Gombrich and Obeyesekere, 1988). It served to project a predominantly religion-based enactment of spirituality in organisations and consequently, the need for connection and 'right' decision-making.

The similarity of different spiritual practices could have contributed to the leaders' common need for a connection with an ultimate and a sense of rightness in decision-making. A number of writers emphasise the similarity of spiritual practices between traditions (Baesler, 2001; Kriger and Seng, 2005; Steele, 2000; Smart, 1991 and 1989; Teasdale, 1997; Vivekananda, 1893; Walker, 1987). For example, Baesler (2001) studied the role of prayer as a spiritual practice in Eastern and Western spiritual traditions and found that, of the many types of prayer among the major world religions, the building block for all types of prayer is the spiritual connection between the individual human being and God. It seems that key spiritual practices within the Buddhist, Hindu, Christian and Muslim traditions seem primarily to advocate the experience of a union of some relationship with an ultimate power. Although it is a connection conceived with different ultimate ideals, the final goal in each tradition is the experience of the incomprehensible and ineffable reality. Therefore, the present study's finding of a common experience of connecting with the ultimate and a common need to make 'right' decisions by the interfaith group of leaders could well have been the result of the similarities that exist between the spiritual practices of different faith traditions. Nevertheless, this merging or connecting one’s self with a larger more powerful and ultimate source of power is a central concept in the extant Western workplace 
spirituality literature. This has been referred to as: extending beyond the mind, body and emotions (Joseph, 2002), interconnectedness (Mitroff and Denton, 1999), faith relationship (Beazley, 1998), spiritual union (Sperry, 1997), relational connections (Goddard, 1995) and connection (Wheat, 1991). Increasing acknowledgement of this connection is evident in Western organisational practice too.

In addition, interfaith studies of spirituality conducted in non-management fields such as neurotheology (e.g. Newberg, D’Aquili and Rause, 2001), health care (e.g. Burkhart, 2001), theology (e.g. Rose, 2001), and psychology (e.g. Piedmont and Leach, 2002) have also found connection to be a common and central concept in our understanding of spirituality. These findings suggest the primacy of connection as a key influence on the need to experience religion-based spirituality in the workplace, and consequently, a sense of rightness in decision-making.

\section{IMPLICATIONS AND RECOMMENDATIONS}

The study reveals the significant role that religion plays in shaping some leaders' desire to make 'right' decisions. The findings of this study support Shakun's (2001) notion of unbounded rationality that argues that decisions are bound not only by cognitive abilities but also by affective and conative faculties. Based on these findings we might speculate that spiritually motivated decision makers will tend to try to go beyond rational and bounded to the unbounded or spiritually-motivated decision-making processes in order to make effective 'right' decisions. When spiritually-motivated leaders are challenged to the extent that they need to reach deeper and draw from their spirituality to find the 'right way' of managing the situation, it is likely that their decision-making process plays a major, if not the dominant, role in determining the outcome.

Therefore, this study highlights the need to accommodate religion in the workplace at least in cultures with high religiosity. Since the practice of religion in the workplace helps 
the religiously motivated leader to seek the help of the ultimate, fostering religion-based workplace spirituality in business organisations might actually improve decision-making. It could influence the behaviour of these organisational members by further complementing the moral and ethical guidelines already in place in order to resolve ethical dilemmas that organisations face.

Another implication arising from the findings of this study is that the leader's transcendent frame of reference during right decision-making is likely to influence the behaviour of such leaders by reinforcing the moral guidelines that are put in place to resolve ethical dilemmas in organisations (Fry, 2005; Parry and Proctor-Thomson, 2002). Business leaders who genuinely operate from religious principles are likely to be highly committed to the well-being of their staff members, as well as other organisational stakeholders. Such leaders could also have an influence on those who come into personal contact with them (Joseph, 2002).

However, as cautioned before, forcing a specific religion based spiritualityparticularly the organisational leader's religion—onto other organisational members could raise some potential concerns. Viewing workplace spirituality through the lens of a specific religious tradition as the only path to the ultimate is divisive because it excludes those who do not share in that tradition. Thus, adopting an inclusive approach should be a necessary goal of organisations practising religion-based spirituality.

It is also important that organisations do not embrace religion-based spirituality simply as a means to become more profitable (Joseph, 2002). Such efforts must be inspired primarily by a sincere desire to holistically engage with increasingly spiritually-motivated organisational members. If not, practising religion-based spirituality could raise genuine concerns about its use, simply to further economic goals of organisations and therefore, has the potential of becoming yet another management fad (Fernando, 2001 and 2005b; Gibbons, 
2000; Jackson, 2001). However, according to the findings of this study, enacting workplace spirituality can be both pragmatic and desirable. It can be pragmatic because it crosses over religious boundaries and cultural contexts. It can be desirable because of the substantial cross-disciplinary evidence which indicates that a heightened level of religiosity and spirituality leads to increased individual well-being (Piedmont and Leach, 2002).

Drawing on the findings of this study and extending Pellebon and Anderson's (1999) guidelines for social workers' treatment of their clients' religious and spiritual needs, the following practices could be used to good effect to foster religion-based spirituality in business organisations. First, one can recognise the contributions that religiously- motivated leaders might be able to bring to the workplace. A stronger sense of values of what is right and wrong, and a concerted effort to recognise organisational members' roles and responsibilities could provide a useful framework for leaders' well-being. Second, organisations should consider creating an atmosphere of support and accommodation of diverse religious and spiritual beliefs by acknowledging the leader's reality. Third, organisations should question the desirability of putting in place procedures to assess the truth of the leader's belief systems. The exception would be when the belief system directly interferes with the leader's functioning or is likely to bring harm in the workplace or to society in general. Finally, organisations should recognise that the spiritual worldview of each member will differ from member to member and take steps not to demean or trivialise member's spiritual worldview. For example, organisational mission statements could acknowledge the right of each employee to "freely interpret the value of Transcendence in their own way" and “...for those who so desire and according to their personal choices, different forms of reflection, meditation, and for some silent and personal prayer during work.” (see http://www.our-project.org). 
Although geographically and culturally, the context of this research was limited to a few highly influential leaders living in Sri Lanka, it raises important questions for future research on decision-making and religion-based workplace spirituality. We believe that future research could profitably focus on the role of connectedness in groups, not only individual decision-making. As Shakun points out (2001), a group problem and solution could be right for all group members, right for some and sometimes, it could be right for no one. Under each of these situations, how would a group members' connectedness be influenced by right problem solving?

The present study was focused on the leaders’ perspective. Future research could compare the findings of this study from other stakeholders' perspectives - such as nonexecutive employees, shareholders, customers and suppliers. This inquiry could be widened to include other participant and industry profiles such as non-managerial staff and organisations from public and not-for profit sectors.

There was strong support for recognising religion-based spirituality in the workplace, particularly in respect to individual well-being, and influencing right decision-making. Future research could compare and contrast the impact on managerial decision-making of those who are motivated by religion-based spirituality and those who are not so motivated. These researchers could conduct studies to test the findings of the present study in Western organizations (see Fernando and Burrows, 2005). Such research would ensure that the findings of the present study were more relevant to mainstream organisations operating in the Western cultures such as Australia and New Zealand.

Consistent with Korac-Kakabadse et al., (2002:172) "Spiritual leaders are moral leaders", and "Spiritual leaders focus on ethical values such as integrity...” (p. 173) and Fry (2003 and 2005), future empirical research might also consider whether religion-based 
spirituality have a significant relationship with such qualities as honesty, integrity and ethical behaviours in organisations.

Acknowledgement: The authors would like to express their gratitude to Ken Parry for his exemplary editorship and four anonymous reviewers for their very helpful feedback on an earlier draft of this paper. In addition we would like to acknowledge the support and encouragement offered by Marion Maddox.

\section{REFERENCES}

Arasaratnam, S (1964) Ceylon, Prentice Hall, New Jersey.

Asian Tribune (2005) Sri Lanka crosses US\$1,000 per capita mark, accessed at http://www.asiantribune.com/show_news.php?id=14297 on 23 February.

Baesler E (2001) The prayer of the Holy Name in eastern and western spiritual traditions: A theoretical, cross-cultural, and intercultural prayer dialogue, Journal of Ecumenical Studies, 38(2/3): 196-217.

Barnett J \& M Karson (1987) Personal values and business decisions: An exploratory investigation, Journal of Business Ethics, 6(5): 371-383.

Batten J, S Hettihewa \& R Mellor (1999) Factors affecting ethical management: Comparing a developed and a developing economy, Journal of Business Ethics, 19(1): 51-60.

Bazerman M (2002) Judgment in Managerial Decision-making, John Wiley: NY.

Beazley H (1998) Meaning and measurement of spirituality in organisational settings: Development of a spirituality assessment scale (Honesty, Humility, Service to others), The George Washington University, USA.

Beyer J (1981) Ideologies, values, and decision-making in organizations, in: Nystrom PC \& William H. Starbuck (eds) Handbook of Organizational Design, Vol. 2, pp 166-202, Oxford University Press, New York. 
Burke L \& M Miller (1999) Taking the mystery out of intuitive decision making, The Academy of Management Executive, 13(4): 91-100.

Burkhart L (2001) Spirituality and religiousness: Differentiating the diagnoses through a review of the nursing literature, Nursing Diagnosis, 2(2): 45-54.

Carter JR (1979) Religiousness of Sri Lanka, Marga, Colombo.

Chandrakumara A \& P Sparrow (2004) Work orientation as an element of national culture and its impact on HRM policy-practice design choices: Lessons from Sri Lanka, International Journal of Manpower, 25(6): 564-589.

Charmaz K (2002) Qualitative interviewing and grounded theory analysis, in: Gubrium J \& J Holstein (eds), Handbook of Interview Research, pp 675-693, Sage, London.

Daft R (2001) Organization theory and design, Southwestern, Cincinnati.

Dent E, E Higgins \& D Wharff (2005) Spirituality and leadership: An empirical review of definitions, distinctions, and embedded assumptions, The Leadership Quarterly, 16(5): 625-653.

Easterby-Smith M, R Thorpe and A Lowe (1991) Management research, Sage, London.

Elliott CB (1938) The Real Ceylon, Ceylon, Caves.

Fernando M (2001) Are popular management techniques a waste of time? The Academy of Management Executive, 15(3): 138-141.

Fernando M (2005a) Self-actualizing workplace spirituality: An empirical study, in: The Proceedings of the Annual Academy of Management Conference, USA, Hawaii. Fernando M (2005b) Workplace Spirituality: Another Management Fad?, in: Adams M and A Alkhafaji (eds), Business Research Yearbook: Global Business Perspectives, Volume XII, No. 2, Ch 19, pp 835-839, International Academy of Business Disciplines, USA.

Fernando M and S Burrows (2005) Unbounded Rationality: The Role of Connectedness 
in Right Decision-making, in: The Proceedings of the Annual Australia New Zealand Academy of Management Conference, Australia, Canberra.

Fritzsche D (1991) A model of decision-making incorporating ethical values, Journal of Business Ethics, 10(11): 841-853.

Fry L (2003) Toward a theory of spiritual leadership, The Leadership Quarterly, 14 (6): 693727.

Fry L (2005) Toward a theory of ethical and spiritual well-being, and corporate social responsibility through spiritual leadership, in: Giacalone RA \& CL Jurkiewicz (eds), Positive Psychology in Business Ethics and Corporate Responsibility, pp 47-83, Information Age Publishing, Greenwich.

Giacalone RA \& CL Jurkiewicz (2003) Toward a science of workplace spirituality, in: Giacalone RA and CL Jurkiewicz (eds), Handbook of Workplace Spirituality and Organizational Performance,Ch 1, pp 3-28, M. E. Sharp, NY.

Giacalone R, C Jurkiewicz \& L Fry (2005) From advocacy to science: The next steps in workplace spirituality research, in: Paloutzian R \& C Park (eds), Handbook of the Psychology of Religion and Spirituality, Ch 28, pp 515-528, Guilford Press, NY.

Gibbons P (2000) Spirituality at work: Definitions, measures, assumptions, and validity claims, in: The Proceedings of the Academy of Management Annual Conference, Toronto, Canada.

Goddard N (1995) The Fourth Dimension: Conceptualisation of Spirituality, Doctoral dissertation, University of Alberta, Canada.

Gombrich R and G Obeyesekere (1988) Buddhism transformed: Religious change in Sri Lanka, Princeton University Press, Princeton.

Harrison E (1999) The Managerial Decision-making Process, (5th ed.), Houghton Mifflin, Boston. 
Hicks D (2002) Spirituality and religious diversity in the workplace. Implications for leadership, The Leadership Quarterly, 13(4): 379-396.

Huitt W (1999) Conation as an important factor of mind. Educational Psychology

Interactive, accssed at http://chiron.valdosta.edu/whuitt/col/regsys/conation.html on 4 June.

Hunt S \& S Vitell (1993) The general theory of marketing ethics: A retrospective and revision, in: Smith NC and JA Quelch (eds), Ethics in Marketing, Irvin, Homewood, IL.

Jackson B (2001) Management gurus and management fashions: A dramatistic inquiry, Routledge, NY.

Jones A (1997) Balasuriya’s ideas on Asia’s future jolt the single-path Vatican view, National Catholic Reporter, 33(16): 9-11.

Joseph M (2002) Leaders and spirituality: A case study, Doctoral dissertation, University of Surrey, United Kingdom.

Korac-Kakabadse N, A Kouzmin \& A Kakabadse (2002) Spirituality and leadership praxis, Journal of Managerial Psychology, 17(3): 165-182.

Kriger M \& Y Seng (2005) Leadership with inner meaning: A contingency theory of leadership based on the worldviews of five religions, The Leadership Quarterly, 16(5): 771-806.

Kriger M \& B Hanson (1999) A value-based paradigm for creating truly healthy Organisations, Journal of Organisational Change Management, 12 (4): 302-317.

Longenecker JG, JA McKinney \& CW Moore (2004) Religious intensity, evangelical Christianity, and business ethics: An empirical study, Journal of Business Ethics, 55: 373-386.

Miles M \& M Huberman (1994) Qualitative Data Analysis, Sage, London. 
Mitroff I \& E Denton (1999) A study of spirituality in the workplace, Sloan Management Review, 40(4): 83-92.

Nanayakkara G (1997) Some reflections of Buddhism on morality in business and management, Sri Lankan Journal of Management, 2(3): 217-232.

Newberg A, E D’Aquili \& V Rause (2001) Why God won’t go away, Ballantine, New York. Niles FS (1994) The work ethic in Australia and Sri Lanka, The Journal of Social Psychology, ProQuest, 134(1): 55-60.

Obeyesekere G (1975) Sinhala Buddhist identity in Ceylon, in: De Vos, G \& L. RomanucciRoss (eds), Ethnic Identity: Cultural Continuities and Change, pp 229-258, Mayfield Publishing, California.

Paloutzian R \& C Park (2005) Integrative themes in the current science of the psychology of religion, in: Palaoutzian R \& C Park (eds), Handbook of Psychology of Religion and Spirituality, Ch 1, pp 3-20, Guilford Press, NY.

Parry K \& S Proctor-Thomson (2002) Perceived integrity of transformational leaders in organisational settings, Journal of Business Ethics, 35(2): 75-97.

Patton M (2002) Qualitative Evaluation Methods, Sage: CA.

Pellebon D \& S Anderson (1999) Understanding the life issues of spiritually-based clients, Families in Society: The Journal of Contemporary Human Services, 80(3): 229-238.

Perera T \& S Buddhadasa (1992) Characteristics of Sri Lankan entrepreneurs: How valid is the Schumpeterian model?, paper presented to the Postgraduate Institute of Management Conference on Management Studies, Colombo.

Piedmont R \& M Leach (2002) Cross-cultural generalizability of the spiritual transcendence scale in India - Spirituality as a universal aspect of human experience, American Behavioral Scientist, 45(12): 1888-1902. 
Ranasinghe S (1996a) Work centrality and job satisfaction: Applicability of the protestant work ethic in the Sri Lankan context, Sri Lankan Journal of Management, 1(1): 1936.

Ranasinghe S (1996b) Entrepreneurship education and training in Sri Lanka, Sri Lankan Journal of Management, 1(3): 262-277.

Rose S (2001) Is the Term 'Spirituality’ a Word that Everyone Uses, But Nobody Knows What Anyone Means by it?, Journal of Contemporary Religion, 16(2): 193-208.

Seale C (2000) The Quality of Qualitative Research, Sage: London.

Shakun M (1999) Consciousness, spirituality and right decision/negotiation in purposeful complex adaptive systems, Group Decision and Negotiation, 8: 1-15.

Shakun M (2001) Unbounded rationality, Group Decision and Negotiation, 10: 97-118.

Simon H (1955) A behavioural mode of rational choice, Quarterly Journal of Economics, 66: 99-118.

Simon H (1956) Rational choice and the structure of the environment, Psychological Review, 63: 129-138.

Simon H (1978) Rationality as a process and product of thought, American Economic Review, 68(2): 1-16.

Singhapakdi A, S Salyachivin, B Virakul \& V Veerayangkur (2000) Some important factors underlying ethical decision-making of managers in Thailand, Journal of Business Ethics, 27(3): 271-285.

Smart N (1989) The world religions: Old traditions and modern transformations, Cambridge University Press, London.

Smart, N (1991) The Religious Experience, MacMillan, New York. Snyder CR \& J Lopez (2001) (eds) Handbook of Positive Psychology, Oxford, New York. 
Sperry L (1997) Leadership dynamics: Character and character structure in executives, Consulting Psychology Journal: Practice and Research, 49(4): 268-280.

Steele S (2000) Christian insight meditation: A test case on interreligious spirituality, Buddhist - Christian Studies, 20: 217-230.

Strauss A \& J Corbin (1990) Basics of Qualitative Research: Grounded Theory Procedures and Techniques, Sage, London.

Tambiah SJ (1986) Sri Lanka: Ethnic Fratricide and the Dismantling of Democracy, The University of Chicago Press, Chicago.

Teasdale W (1997) The interspiritual age: Practical mysticism for the third millennium, Journal of Ecumenical Studies, 34(1): 74-92.

Vivekananda S (1893) Paper on Hinduism, World Parliament of Religions, accessed at http://www.itihaas.com/modern/vivek-speech3.html on 16 February 2004.

Walker S (1987) (ed) Speaking of Silence: Christians and Buddhists on the Contemplative way, Paulist Press, New York.

Weick K (1979) The Social Psychology of Organizing, Addison-Wesley, Massachusetts.

Weick K (1995) Sensemaking in Organizations, Sage, California.

Wheat L (1991) Development of a Scale for the Measurement of Human Spirituality, University of Maryland, USA.

Whittington JL, TM Pitts, WV Kageler \& VL Goodwin (2005) Legacy leadership: The leadership wisdom of the Apostle Paul, The Leadership Quarterly, 16(5): 749-770. Zinnebauer BJ \& KL Paragament (2005) Religiousness and spirituality, in: Paloutzian R \& C Park (eds), Handbook of the Psychology of Religion and Spirituality, Ch 2, pp 21-42, Guilford Press, NY. 


\section{TABLE 1}

\section{Extracts from the Spirituality Statement File}

1. How you set out in your life RIGHT CONDUCT

2. Protection from harm PROTECTION

3. Helpful to society HELP COMMUNITY

4. Religion influences spirituality because it gives you lessons on what is right and wrong RIGHT AND WRONG

5. All the religions have these so it all starts from religion RELIGION IS THE SOURCE

6. At least with religion, there is some kind of a compass RELIGION IS A COMPASS

7. I don't know the truism of life, the purpose, who defines it - God, you, work, government, teachers, parents? LACK OF KNOWLEDGE ABOUT PURPOSE OF LIFE AND WHO DETERMINES IT

8. Spirituality without religion is possible but darker because there is no starting point or guiding light SPIRITUALITY WITHOUT A RELIGION IS POSSIBLE 
TABLE 2

\section{Right Decision-making - Interview Excerpts}

\begin{tabular}{|c|c|}
\hline Participant & Sense of Rightness \\
\hline Buddhist \#1 & $\begin{array}{l}\text { In fact, as far as the business is concerned, all I say is that I apply myself in } \\
\text { my business dealings in doing what I believe is the right course of conduct. }\end{array}$ \\
\hline Buddhist \#2 & $\begin{array}{l}\text { I pray daily for assistance in my Karma and to carry out the work in the right } \\
\text { way. }\end{array}$ \\
\hline Buddhist \#3 & $\begin{array}{l}\text { We are doing business! Then through this business, we can give our } \\
\text { righteousness (dharmaya) to our people. }\end{array}$ \\
\hline Buddhist \#4 & $\begin{array}{l}\text { I think religion influences spirituality because it gives you the first lessons of } \\
\text { what is right and wrong. }\end{array}$ \\
\hline Buddhist \#6 & Even now, I think within those five precepts, whether I was right o \\
\hline Hindu \#1 & $\begin{array}{l}\text { I sit and think and pray to God. Am I doing the right thing, am I going the right } \\
\text { way? I do go back to God and say please help me to do this. For example, with } \\
\text { a } 300 \text { million-rupee project, I have to make the right decisions. }\end{array}$ \\
\hline $\begin{array}{l}\text { Roman } \\
\text { Catholic \#1 }\end{array}$ & $\begin{array}{l}\text { My understanding of spirituality is an action based on your convictions that } \\
\text { whatever right is to be accepted and I don't think spirituality comes only from } \\
\text { my religion. I think spirituality comes from everybody else who does the right } \\
\text { thing... what 'right' is, what does not hurt the other person- } \underline{\text { right from not my }} \\
\text { point of view but from the other person's point of view. Spirituality does not } \\
\text { come from dogmatic teaching. It comes from doing what is right. }\end{array}$ \\
\hline Muslim \#1 & $\begin{array}{l}\text { I see spirituality as referring to values, the rights and wrongs which I think is } \\
\text { professed across all religions. }\end{array}$ \\
\hline
\end{tabular}


FIGURE 1

Data analysis process: An illustration

\author{
Group $\longrightarrow$ Theme $\longrightarrow$ Category $\longrightarrow$ Concept \\ Spirituality Doing meaningful \\ Altruism \\ Accommodating \\ charity \\ others
}

Right conduct Practising values Practising values

Praying to entity Practice of faith Connecting with

the external

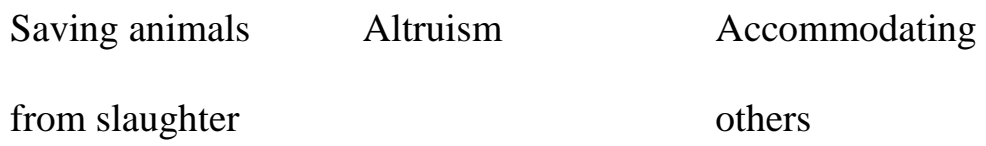

Self-reflection Self-reflection Connecting with Self 